\title{
The Definition of Trafficking in Adult Persons for Various Forms of Exploitation and the Issue of Consent: A Framework Approach that Respects Peculiarities
}

Dr. Silvia Scarpa ${ }^{1}$

DOI: $10.21827 / 5 a 86 a 7 a f d c 32 e$

\begin{abstract}
Keywords
TRAFFICKING, CONSENT, DEFINITION, EXPLOITATION OF THE PROSTITUTION OF OTHERS, SEXUAL EXPLOITATION, FORCED LABOUR OR SERVICES, SLAVERY, PRACTICES SIMILAR TO SLAVERY, SERVITUDE, REMOVAL OF ORGANS.
\end{abstract}

\begin{abstract}
The article discusses the problems determined by the interpretation of the definition of trafficking in adult persons contained in Article 3(a) of the UN Trafficking Protocol as including the element of the improper means and vitiated consent. In particular, it examines whether consent is an issue in the definitional frameworks related to the forms of exploitation associated with trafficking and formulates a recommendation to take eventual definitional conflicts into consideration.
\end{abstract}

\section{Introduction}

The aim of this article is to analyse the definition of trafficking in adult persons included in Article 3(a) of the Protocol to Prevent, Suppress and Punish Trafficking in Persons, Especially Women and Children adopted in Palermo in 2000 (UN Trafficking Protocol) and the forms of exploitation associated with it, namely 'the exploitation of the prostitution of others or other forms of sexual exploitation, forced labour or services, slavery or practices similar to slavery, servitude or the removal of organs'. The international frameworks created for the purpose of fighting against these practices are in some respects conflicting with the element of the improper means and the issue of consent as included in the UN Trafficking Protocol's definition. Therefore, a recommendation is formulated to the Conference of the Parties-- established according to Article 32.1 of the Convention against Transnational Organized Crime--and to the States Parties to better determine the importance to be assigned to the issue of consent and the use of improper means, as well as the relationship between trafficking and practices that are associated with it as forms of exploitation when implementing and reviewing trafficking legislation in national penal law.

Adjunct Professor of Political Science, John Cabot University and Adjunct Professor of International Law, LUISS Guido Carli University of Rome, Italy. 


\section{The International Definition of Trafficking in Persons: A Historical Analysis}

In 2000, the adoption of the UN Trafficking Protocol saw the introduction into international law of the first definition of "trafficking in persons". The concept of "trafficking" was not completely new though; it was instead an evolution of the term "traffic" that, since the beginning of the XIX century, had been used with reference to the phenomenon of the "white slave traffic", namely the abduction of European adult women and young girls, their transportation abroad and their final exploitation in brothels. Four main international treaties were adopted in the first part of the XX century for the purpose of fighting against this phenomenon, namely the 1904 International Agreement for the Suppression of the White Slave Traffic, ${ }^{2}$ the 1910 International Convention for the Suppression of the White Slave Traffic, ${ }^{3}$ the 1921 International Convention for the Suppression of the Traffic in Women and Children ${ }^{4}$ and, finally, the 1933 International Convention for the Suppression of the Traffic in Women of Full Age. ${ }^{5}$ None of them gave a definition of the phenomenon of the white slave traffic but they all made reference to the procurement of women for "immoral purposes", ${ }^{6}$ which was their common denominator. It is interesting to emphasise that none of the white slave traffic conventions dealt with prostitution per se, which remained a matter of national jurisdiction. Moreover, the 1921 and 1933 conventions were adopted under the auspices of the League of Nations, ${ }^{7}$ which had also promoted the adoption of the 1926 Convention on Slavery aimed at fighting against slavery and the slave trade. ${ }^{8}$

The scope of the white slave traffic conventions was consolidated and extended by the 1949 Convention for the Suppression of the Traffic in Persons and the Exploitation of the Prostitution of Others, whose adoption was promoted by the United Nations. ${ }^{9}$ Seven years after the adoption of the 1949 Convention, the United Nations promoted the adoption of the Supplementary Convention on the Abolition of Slavery, the Slave Trade and Institutions and Practices Similar to Slavery, ${ }^{10}$ that was aimed at fighting against debt bondage, serfdom and any institution and practice whereby women and children can be transferred by a person to another in a servile status. ${ }^{11}$

Therefore, the two branches of international law dealing with slavery and the slave trade and the traffic in persons--previously known as the white slave traffic-- were kept by the

2 The International Agreement for the Suppression of the White Slave Traffic, 1904, 1 LNTS 83.

3 The International Convention for the Suppression of the White Slave Traffic, 1910, 8 LNTS 278.

4 The International Convention for the Suppression of the Traffic in Women and Children, 1921, 9 LNTS 415.

5 The International Convention for the Suppression of the Traffic in Women of Full Age, 1933, 150 LNTS 431.

6 See, for instance, Article 1 the 1904 International Agreement for the Suppression of the White Slave Traffic and Article 1 of the 1910 International Convention for the Suppression of the White Slave Traffic.

7 Article 23(c) of the Covenant of the League of Nations attributed to this international organization the supervision on the international agreements in the field of the traffic in women and children.

8 The Slavery, Servitude, Forced Labour and Similar Institutions and Practices Convention on Slavery, 1926, 60 LNTS 253.

9 The Convention for the Suppression of the Traffic in Persons and of the Exploitation of the Prostitution inof Others, 1951, 96 UNTS 271.

10 The Convention, the United Nations promoted the adoption of the Supplementary Convention on the Abolition of Slavery, the Slave Trade and Institutions and Practices Similar to Slavery, 1949, 266 UNTS 3.

11 Article 7 of the Supplementary Convention on the Abolition of Slavery, the Slave Trade and Institutions and Practices Similar to Slavery. 
League of Nations and the United Nations--at least since the 1970s--clearly distinguished and there was no overlapping among them. The line separating them becomes blurred when, in 1974 the Economic and Social Council established the Working Group on Slavery. The mandate of the latter body comprised not only slavery and the slave trade 'in all their practices and manifestations', but also the traffic in persons and the exploitation of the prostitution of others. ${ }^{12}$ Moreover, in its 30 years of activity the Group did not strictly abode to its mandate and it dealt with many other exploitative practices. In 1988, it was also renamed the Working Group on Contemporary Forms of Slavery, as a way to acknowledge its interest in exploitative practices that were considered as being 'new forms of slavery'. In this respect, it becomes evident how the two branches of international law dealing with slavery and the slave trade and the traffic in persons-- intended by the Working Group as including various forms of exploitation and not only the prostitution of others ${ }^{13}$--started to be considered as different part of the same broad category of "contemporary slavery" that remains undefined under international law.

This historical analysis clarifies better that the UN Trafficking Protocol's definition of "trafficking in persons" did not emerge in a vacuum. It is instead the final step of the process of approachment among these two branches of international law.

\section{The Complexity of the Protocol's Definition of Trafficking in Adult Persons Explained}

The definition of trafficking in adult persons included in Article 3.(a) of the UN Trafficking Protocol is composed by three elements: 1. an action--namely 'the recruitment, transportation, transfer, harbouring or receipt of persons'; 2 . the use of improper means by traffickers--including 'the threat or use of force or other forms of coercion, of abduction, of fraud, of deception, of the abuse of power or of a position of vulnerability or of the giving or receiving of payments or benefits to achieve the consent of a person having control over another person'-- to achieve the consent of the victims; 3 . for the purpose of exploitation, including inter alia 'the exploitation of the prostitution of others and other forms of sexual exploitation, forced labour or services, slavery and practices similar to slavery, servitude or the removal of organs'. Article 3.(b) then clarifies that in cases in which any of the improper means included in the definition is used, the consent of the victim to the intended exploitation is irrelevant.

This definition suffers from the fact that it tries to incorporate various definitions into a single concept, namely "trafficking in persons", exploitative practices and the international systems aimed at fighting against them and it has, consequently, multiple "souls". First of all, it inherently suffers from the complexity of the previous white slave traffic conventions, in so much as it focuses on the process of trafficking individuals. The main difference with the white slave traffic conventions is, however, the fact that the Trafficking Protocol's

12 The mandate also comprised apartheid and colonialism, as forms of "collective slavery". The reference to these two issues can be more easily understood taking into consideration the historical period in which such inclusion was made. They are not of relevance for the analysis conducted in this article, therefore, they are not taken into consideration.

13 See, for instance, the reference to "traffic in human organs" included in the 1996 Commission on Human Rights Report, 1996, Un Doc. E/CN.4/Sub.2/1996/24 of 19 July 1996, the traffic affecting children, including the phenomenon of child soldiers and the "illegal traffic for the purpose of adoption" in the Commission on Human Rights Report, 1997, UN Doc. E/CN.4/Sub.2/1997/13 of 11 July 1997, and the one to "traffic of migrant workers" in the Commission on Human Rights Report, 1998 UN Doc. E/CN.4/Sub.2/1998/14 of 6 July 1998. 
definition includes in such a process other practices aside to the exploitation of the prostitution of others or other forms of sexual exploitation. A comparison can be made, instead, between the slave trade as being the process that leads to slavery and trafficking in persons as the one that is connected to various exploitative practices. Nevertheless, also in this case, the difference between a system based on the absolute prohibition of slavery, which is to be implemented by States on the basis of the 1926 definition of slavery and the one of the exploitation of the prostitution of others and other forms of sexual exploitation, which are practices whose definitions, boundaries and regulation are a matter of national jurisdiction, is evident.

On the other hand, if one analyses forced labour, the practices similar to slavery, servitude and the removal of organs, a conclusion can be reached that the Trafficking Protocol's definition connects them for the first time with a process-oriented crime. This process, however, can be long and actions can happen in different moments and places, thus making the prosecution of trafficking cases extremely complex.

Finally, the issue of consent included in the second element of the definition was a highly contested issue during the negotiations that led to the adoption of the UN Trafficking Protocol. However, the debate on its relevance was only conducted in respect of one specific form of exploitation, namely the exploitation of the prostitution of others or other forms of sexual exploitation. Notwithstanding this, as it currently stands, the issue of improper means being used to achieve the consent of trafficking victims applies equally to cases of trafficking in adult persons for all the other exploitative purposes enlisted in the definition. An analysis of these other practices shows, however, that there might be clashes between the way in which the trafficking framework takes into consideration the issue of consent and the one in which some of these practices are defined according to international law.

All the forms of exploitation included in the UN Trafficking Protocol's definition are left undefined; the analysis that follows provides a clarification on how they should be defined and examines how the elements of these definitions fit the ones included in the trafficking framework, focusing in particular on the issue of consent and the use of improper means.

\section{III.1. Trafficking in Persons for the Purpose of the Exploitation of the Prostitution of Others or Other Forms of Sexual Exploitation}

The exploitation of the prostitution of others and other forms of sexual exploitation constitute the classical practices associated with the concept of trafficking since the end of the XIX century. They represent the modern translation and clarification of the white slave traffic convention's reference to "the immoral purposes", which proves to be the reasons why young women and girls were transported abroad. In this respect, there is a general continuity: the white slave traffic conventions adopted in the first part of the XX century were received as a framework for States to co-operate for the purpose of eliminating the process of recruitment and transportation abroad of women for "immoral purposes". At the same time, States were very much determined to keep prostitution--and the way in which the practice should be defined--as a matter of national jurisdiction. The only treaty that had made a step in advance in this respect, namely the 1949 Convention for the Suppression of the Traffic in Person and the Exploitation of the Prostitution of Others--which was considered as an abolitionist treaty--had not been ratified by many States, which preferred to keep the regulation of such practice as a matter of national jurisdiction.

As regards the UN Trafficking Protocol, the Travaux Préparatoires clarify that the exploitation of the prostitution of others and other forms of sexual exploitation are not 
defined by it and that "the Protocol is therefore without prejudice to how States address prostitution in their respective domestic laws". ${ }^{14}$

The UN Trafficking Protocol can, consequently, only offer a framework of cooperation for States in respect of trafficking for the purpose of the exploitation of the prostitution of others and other forms of sexual exploitation. It is difficult, however, to guarantee consistency when States Parties remain free to interpret the practice of trafficking in persons for the exploitation of the prostitution of others and other forms of sexual exploitation as they wish. In this respect, unfortunately, the conclusion reached by Nanda and Bassiouni more than forty years ago - that if one compares the system aimed at prohibiting slavery and the slave trade with the one on the white slave trade or traffic, a conclusion can be reached that the latter was less effective, because a change in the basic values, which permit to tolerate that practice, has never happened ${ }^{15}$ - is still accurately representing the reality and can also be extended to the efficacy of the international framework aimed at fighting against trafficking in persons for the exploitation of the prostitution of others and other forms of sexual exploitation.

\section{III.2. Trafficking in Adult Persons for the Purpose of Forced Labour or Services}

The analysis of the practice of forced labour as included in the trafficking definition offers interesting perspectives, too. The international definition of forced labour is included in Article 2.(1) of the International Labour Convention (ILO) n. 29, ${ }^{16}$ adopted by the International Labour Organization (ILO) in 1930. Accordingly, forced or compulsory labour is 'all work or service which is exacted from any person under the menace of a penalty and for which the said person has not offered himself voluntarily'.

The original, main aim of the ILO Convention n. 29 was to fight against forced labour imposed by States, and in that respect the reference to a penalty was more easily understandable; ${ }^{17}$ however, article 4(1), adds that States Parties shall not permit the imposition of forced labour 'for the benefit of private individuals, companies or associations'.

The ILO clarifies that this definition of forced labour contains two main elements, namely the menace of a penalty and the involuntariness. The interpretation provided by the ILO of these two elements has recently seen an evolution. The menace of a penalty was originally associated with psychological or physical coercion and the involuntariness with the idea that individuals 'perform some work that they would otherwise not have accepted

14 United Nations, General Assembly (LV), REPORT: Report of the Ad Hoc Committee on the Elaboration of a Convention against Transnational Organized Crime on the work of its first to eleventh sessions Addendum- Interpretative notes for the official records (travaux préparatoires) of the negotiation of the United Nations Convention against Transnational Organized Crime and the Protocols thereto, 3 November 2000, U.N. Doc. A/55/383/Add.1, 12.

15 Nanda, V.P. and Bassiouni, M.C., "Slavery and the Slave Trade: Steps Towards Eradication", Santa Clara Lawyer, vol. 12, , ed. 2, 1972, 424-442.

16 Convention Concerning Forced or Compulsory Labour, 1930, 39 UNTS 55.

17 In this respect an interesting issue arises: can the offense of trafficking in persons for the purpose of forced labour, as defined by the UN Trafficking Protocol, be committed by States? It would seem obvious from the text of the Protocol that this is not the case, however, the lack on any specific clarification or indication on how to interpret the concept of "forced labour" in the Travaux Préparatoires is to be noted. 
to perform at the prevailing conditions' ${ }^{18}$ More recently, the ILO proposed to interpret the term menace of a penalty as including:

criminal sanctions as well as various forms of coercion such as threats, violence, the retention of identity documents, confinement, or non-payment of wages. The penalty may also take the form of a loss of rights or privileges. ${ }^{19}$

It is worth noting that coercion is included in the list of improper means included in the UN Trafficking Protocol's definition of trafficking in adult persons and it seems to be considered similar to the use of force. There is, therefore, an overlapping in this respect between a fundamental characteristic of forced labour and an improper mean included in the UN Trafficking Protocol's definition. It is not clear, however, whether and how this produces impacts on the issue of consent, as taken into consideration by the UN Trafficking Protocol's definition. Psychological or physical coercion can be considered as a very strong form of pressure that completely overrides discussions on consent by the victim.

However, the UN Trafficking Protocol's definition also refers to other improper means such as 'abduction, fraud, of deception, of the abuse of power or of a position of vulnerability or of the giving or receiving of payments or benefits to achieve the consent of a person having control over another person' and they might eventually overlap with the elements indicated by the ILO. For example, the retention of identity documents and the non-payment of wages might be related to deception or fraud. Moreover, if coercion is already an element of the crime of forced labour, the relevance of the other improper means in this respect is scarce. Moreover, since the definition also refers to the element of involuntariness, which is considered as being by Nowak 'a fundamental, definitional feature $^{20}$ of forced labour, the lack of consent is already included as an element of this crime.

\section{III.3. Trafficking in Adult Persons for the Purpose of Slavery, Practices Similar to Slavery and Servitude}

The UN Trafficking Protocol's definition also includes, among the forms of exploitation associated with trafficking in persons, slavery, practices similar to slavery, and servitude. Slavery is defined by Article 1.1 of the 1926 Slavery Convention as being "the status or condition of a person over whom any or all of the powers attaching to the right of ownership are exercised". In this respect it is interesting to emphasise that this definition of slavery does not contain any reference to the issue of consent. Slavery, as defined by the 1926 Slavery Convention, can in fact be both voluntary and involuntary. ${ }^{21}$ The inclusion of slavery among the practices that can constitute the end result of the process of adult

18 Belser, P., De Cock, M. and Mehran, F., ILO Minimum Estimate of Forced Labour in the World, International Labour Organization, 2005, 7-8, available online at <ilo.org/wcmsp5/groups/public/---ed_norm/--declaration/documents/publication/wcms_081913.pdf> (accessed 28 November 2013).

19 International Labour Organization, Combating Forced Labour: A Handbook for Employers and Business, International Labour Office Publications, Geneva, 2008, available online at $<$ ilo.org/wcmsp5/groups/public/---ed_norm/---declaration/documents/publication/wcms_101171.pdf> (accessed 8 November 2013).

20 Nowak, M., "Article 8: Prohibition of Slavery", in: Nowak, M., U.N. Covenant on Civil and Political Rights: CCPR Commentary., 2 rev. ed., N.P. Engel, Kehl am Rhein, Engel, 2005, 201.

21 Ibid. Nowak underlines the fundamental difference between slavery and servitude on one side and forced labour on the other, looking exactly at the fact that the former offences are prohibited both in the event of voluntariness and involuntariness. 
trafficking--done by the UN Trafficking Protocol--leads to the outcome that an additional issue is to be taken into consideration when examining a case of adult trafficking for the purpose of slavery: that consent was given but was vitiated by the use of improper means.

Similar conclusions can be reached for the so-called 'practices similar to slavery'. These practices are defined by Article 1 of the Supplementary Convention on the Abolition of Slavery, the Slave Trade and Institutions and Practices Similar to Slavery as including:

(a) Debt bondage, that is to say, the status or condition arising from a pledge by a debtor of his personal services or of those of a person under his control as security for a debt, if the value of those services as reasonably assessed is not applied towards the liquidation of the debt or the length and nature of those services are not respectively limited and defined;

(b) Serfdom, that is to say, the condition or status of a tenant who is by law, custom or agreement bound to live and labour on land belonging to another person and to render some determinate service to such other person, whether for reward or not, and is not free to change his status;

(c) Any institution or practice whereby: (i) A woman, without the right to refuse, is promised or given in marriage on payment of a consideration in money or in kind to her parents, guardian, family or any other person or group; or (ii) The husband of a woman, his family, or his clan, has the right to transfer her to another person for value received or otherwise; or (iii) A woman on the death of her husband is liable to be inherited by another person. ${ }^{22}$

By definition, debt bondage, as slavery, might include both voluntary and involuntary cases. Its reference to the "pledge by a debtor" may in fact be interpreted as involving an acceptance to repay the debt with services, while on the other hand the reference to "person under [the] control" raises the issue of members of the family who might be obliged to contribute to the repayment of the debt. In this respect, debt bondage can in fact comprehend both cases of individuals who are consenting to it and those who do not take part in it voluntarily.

A case of adult trafficking for the purpose of debt bondage would not only be identified with reference to the elements included in the definition of debt bondage, but also taking into consideration the improper means and the issue of consent. However, voluntary debt bondage would end up being excluded a priori from the trafficking framework, when the use of improper means cannot be demonstrated. On the other hand, assuming that debt bondage--at least in its traditional form--is often related to conditions of poverty, illiteracy, discrimination (including, in particular, the one based on ethnic, caste and gender grounds), one should speculate on the way in which the abuse of power or of a position of vulnerability should be interpreted so as to include the situations in which individuals consent to such exploitation for lack of real and viable alternatives. Therefore, an interpretation of the abuse of power or position of vulnerability concepts, as used in the UN Trafficking Protocol and how it is transformed in national legislation by States Parties, is

22 Supplementary Convention on the Abolition of Slavery, the Slave Trade, and Institutions and Practices Similar to Slavery, 1956, 266 UNTS 3. The definition also refers to '(d) Any institution or practice whereby a child or young person under the age of 18 years, is delivered by either or both of his natural parents or by his guardian to another person, whether for reward or not, with a view to the exploitation of the child or young person or of his labour'. However, since this article only focuses on trafficking in adult persons, this practice similar to slavery concerning only children is not taken into consideration. 
fundamental. It would in fact prove useful for the purpose of better understanding how trafficking legislation could eventually be used for the purpose of fighting against cases of debt bondage.

As regards serfdom, the use of the term "bound" in the definition of this term might be interpreted as implying an obligation determined by "custom or agreement". ${ }^{23}$ The main characteristics of the definition of this practice are, however, to be identified in the obligation to live and work on a specified plot of land belonging to someone else, to render certain services to the landowner and in the impossibility to leave. Serfdom might, consequently, be either voluntary or involuntary, so that conclusions similar to the ones reached for debt bondage would apply to this practice too.

Finally, for what concerns the practices regarding women--indicated in Article 1.(c) of the Supplementary Convention on the Abolition of Slavery, the Slave Trade and Institutions and Practices Similar to Slavery--it seems evident from an analysis of the definition that the victim's consent is lacking. In this respect, a clash is evident between the definition of trafficking in adults and the definition of these various practices. The former considers in fact improper means as a way to demonstrate that consent is vitiated. On the other hand, the latter is focused on two elements: first, the fact that the decision regarding the woman is taken by someone else and, secondly, that the final outcome of the decision--the marriage, the transfer or the inheritance of the woman--cannot be challenged by her. Therefore, also in this case doubts might arise as to the applicability of the trafficking framework to these practices affecting women, as the use of improper means should also be demonstrated.

No international treaty defines the term 'servitude', which was however, included in some international human rights conventions. This includes, at the universal level, Article 4 of the Universal Declaration of Human Rights, Article 8.2 of the International Covenant on Civil and Political Rights, and Article 11.1 of the International Convention on the Protection of the Rights of all Migrant Workers and Members of their Families. At the regional level it includes Article 4.1 of the European Convention on Human Rights (ECHR), Article 5.1 of the Charter of Fundamental Rights of the European Union, ${ }^{24}$ Article 6 of the 1969 American Convention on Human Rights, which however prohibits only "involuntary" servitude, and Article 10.1 of the 2004 Arab Charter on Human Rights.

However, its contours remain vague. For instance, Nowak concludes that the Travaux Préparatoires of the United Nations International Covenant on Civil and Political Rights (ICCPR) clarify that slavery has to be intended in its traditional sense, as implying the "destruction of one's juridical personality", while servitude had to be associated with "dominance and degradation". On the other hand, in Siliadin v. France, the European Court of Human Rights defined servitude as being 'an obligation to provide one's services that is imposed by the use of coercion, and is to be linked with the concept of 'slavery'. ${ }^{25}$

Therefore, there is a primary difficulty associated with the analysis of the practice of servitude as included in the UN Trafficking Protocol's definition, namely the lack of a clear international definition or of general contours for the purpose of identifying its characteristics and differentiating it from other exploitative practices, such as slavery, practices similar to slavery and forced labour. Moreover, as regards the issue of consent in respect of servitude, it is interesting to note that, during the drafting process of the Universal Declaration of Human Rights, the Commission on Human Rights had recommended the

\footnotetext{
${ }^{23}$ The reference to law is not taken into consideration as the legal institution of serfdom should have been abolished worldwide.

${ }^{24}$ It is worth noting that, according to the Treaty of Lisbon, the Charter has the same legal value as the treaties.

${ }^{25}$ European Court of Human Rights, 26 October 2005, Siliadin v. France, App. No. 73316/01, para. 124.
} 
addition of the adjective "involuntary" as a way to better qualify the term "servitude". ${ }^{26}$ However, this proposal was not accepted by the third Committee of the General Assembly of the United Nations as it was believed that it was necessary to eliminate servitude whether it was voluntary or not, and to avoid offering to slave holders the possibility of arguing that their victims had accepted such a condition in a voluntary way. ${ }^{27}$ Thus, also in this case difficulties arise when trying to combine the constituent elements of the practice of servitude with the ones associated with the trafficking framework included in the UN Trafficking Protocol.

\section{III.4. Trafficking in Adult Persons for the Purpose of the Removal of Organs}

The removal of organs is the last form of exploitation that is specifically included in the UN Trafficking Protocol's definition of trafficking in persons. A major difference in respect of other exploitative practices included in the definition of human trafficking is the fact that the practice of removing organs can be conducted on both living donors and post-mortem. However, the latter can be excluded from this analysis, as it can legitimately be assumed that the definition of trafficking in persons does not refer to cadavers, but only to living individuals.

It should also be clarified that many States allow the removal of organs from living donors and they regulate the practice according to their national legislation in the field. Thus, a major difference with other practices included in the trafficking definition, such as slavery, servitude or practices similar to slavery, is that there is no absolute prohibition and criminalisation of the removal of organs under international law; the practice can legitimately be conducted, according to the rules and limitations established by national laws in this field. It is worrying that in the field of the removal of organs there is no universal treaty establishing minimum rules on prohibited conducts or common frameworks. On the other hand, a regional framework is to be found in the Council of Europe Convention on Human Rights and Biomedicine and its Additional Protocol on Organs and Tissues of Human Origin.

According to the United Nations and the Council of Europe, trafficking in human beings for the purpose of the removal of organs is part of a broader phenomenon: trafficking in organs, tissues and cells. The Report jointly published by these two international organizations defines the latter as:

(a) the illicit removal, preparation, preservation, storage, offering, distribution, brokerage, transport or implantation of organs, tissues and cells [...]; and (b) the possession or purchase of organs, tissues or cells with a view to conducting

26 United Nations Economic and Social Council, Commission on Human Rights, REPORT: Report and Summary Record of the Third Session of the Commission on Human Rights, 28 June 1948, UN Doc. E/800, 11, New York; Commission on Human Rights, Summary Record of the Fifty-Third Meeting, UN Doc. E/CN.4/SR.53, 3, New York.

27 United Nations General Assembly, REPORT: Report of the Third Committee on the third session of the General Assembly, 7 December 1948, UN Doc. A/777; United Nations General Assembly, Summary Record of the Hundred and Ninth Meeting, 21 October 1948, UN Doc. A/C.3/SR.109, Paris, and United Nations General Assembly, Summary Record of the Hundred and Tenth Meeting, 22 October 1948, UN Doc. A/C.3/SR.110, Paris. 
one of the activities listed in (a); solely for financial or other economic gain (for this or a third person's benefit). ${ }^{28}$

The Report fails, however, to take into consideration the fact that the UN Trafficking Protocol's definition makes reference to the improper means and the issue of consent only in respect of adults, but not for children. ${ }^{29}$ It also claims that trafficking in persons for the removal of organs is only a "marginal phenomenon", ${ }^{30}$ a tiny fraction of the general phenomenon of trafficking in organs, tissues and cells. It is not well clarified how this conclusion was reached by the Report. However, one might speculate on the fact that it is probable that this depends very much on the way in which the phenomenon is defined and included in States Parties' national penal laws. Moreover, the focus on victims' consent and the use of improper means associated with the trafficking framework distracts the attention from the main issues: that the removal of organs is conducted in an illegal way and that the final purpose of the traffickers is to obtain a financial or other material benefit.

\section{Concluding Remarks}

The definition of trafficking in adult persons contained in Article 3(a) of the UN Trafficking Protocol represents a compromise among the States' representatives that participated in the negotiations process. While the reference to trafficking as related to multiple forms of exploitation is very much relevant for the purpose of fighting against the complex and varied practices existing worldwide, a rigid interpretation of such a framework does not support such aims and instead risks undermining it. Therefore, a recommendation is formulated to the Conference of the Parties (established according to Article 32.1 of the Convention against Transnational Organized Crime) as well as the States Parties to the Protocol, to promote an interpretation of the definition of trafficking in adult persons in their national penal laws that takes into consideration the multiple frameworks constituted by the various forms of exploitation associated with it. Additionally, they should not place the issue of consent and the related improper means in a cage that hinders the fight against this odious phenomenon of our time.

www.grojil.org

28 United Nations and Council of Europe, Joint Study on Trafficking in Organs, Tissues and Cells and Trafficking in Human Beings for the Purpose of the Removal of Organs, Council of Europe, 2009, 13. I had also previously referred to the two phenomena, respectively, in terms of trade or market in human organs and trafficking in human organs, see Scarpa, S., Trafficking in Human Beings: Modern Slavery, Oxford University Press, Oxford, 2008, 34-39.

29 Idem, 13.

30 United Nations and Council of Europe 2008, supra nt. 28, 93. 